\title{
Control of Pinyon Saplings with Picloram
}

\section{or Karbutilate}

\section{JAMES A. YOUNG AND RAYMOND A. EVANS}

Highlight: The herbicides picloram or karbutilate were used to kill one-leaf pinyon saplings that form dense stands in areas that were previously chained to remove large trees. The granular herbicides were applied to the soil beneath the crown spread of the saplings by pouring the herbicide on top of the trees and allowing it to trickle down through the branches. Both materials were effective at low rates. If desirable shrubs or herbaceous species were not rooted directly beneath the tree canopies, minimum damage resulted from the herbicide application. Herbage production was not significantly increased or decreased by removal of the pinyon saplings with herbicides. Cutting the saplings and shrubs by hand and removing them from the plot increased herbage production.

Chaining, the uprooting or breaking-off of trees by dragging an anchor-chain between large tractors, has been widely used by land managers in the pinyon (Pinus monophylla)/ Utah juniper (Juniperus osteosperma) woodlands of the Great Basin. The goal of these mechanical treatments of closed canopy woodlands is to induce a lower stage of succession dominated by grasses, forbs, and browse species that can be harvested by domestic livestock, wildlife, or both. Many chainings have failed to achieve this goal because of the rapid growth and assumption of dominance by sapling pinyon, juniper, or both that were supple enough to bend with the chain and snap back after it passed (Monroe, 1974). The obvious solution to this problem is to chain only areas that support closed canopy, old growth trees, so a minimum number of small trees are present to escape the mechanical treatment.

The authors are range scientists, Agricultural Research Service, U.S. Department of Agriculture, Renewable Resource Center, University of Nevada, 920 Valley Road, Reno, Nev. 89512 .

This report is a cooperative investigation of the Agricultural Research Service, U.S. Dep. Agr., and the Agricultural Experiment Station, University of Nevada, Reno, Nev. Journal Series No. 297.

Manuscript received January 25, 1975. Neither karbutilate nor picloram is registered by the Environmental Protection Agency (EPA) for the use on grazing lands described in this paper. Picloram is registered for control of pinyon or juniper on rangelands within some, but not all western states. Before using either of these materials, check with local state departments of agriculture and/or EPA offices.
The pinyon/juniper woodlands of the Great Basin are usually on mountainous topography with a wide variety of topo-edaphic situations in a given area. Extensive disturbance by wood, post, and charcoal cutting with promiscuous burning often has produced a number of different successional stages within a given woodland stand (Beeson, 1974). To chain desired areas, land managers have often been forced to treat a matrix of closed stands dotted with islands of younger successional stages. They did so because of accepted economic concepts that large blocks must be treated and because the implement requires relatively large areas for maneuvering. To make chaining an acceptable range improvement practice, irregular boundaries must be blended aesthetically into the landscape. It is difficult to design this type of mechanical treatment without including low seral communities. Therefore, the problem of management of mixed stands still persists in many areas. Our purpose was to develop methods of controlling saplings of one-leaf pinyon in areas that had previously been mechanically treated to control larger trees.

\section{Methods}

The study area was in Churchill Canyon, about $17 \mathrm{~km}$ northwest of Yerington, Nevada. The site was located in the upper one-third of the pinyon/juniper zone at an elevation of $1,965 \mathrm{~m}$ on the eastern escarpment of the Pine Nut Mountain Range. Annual precipitation (based on a recorder near the site) averages $285 \mathrm{~mm}$, confined almost entirely to cold winter storms.

The area was chained with an anchor chain, aerially seeded to crested wheatgrass (Agropyron desertorum) and bitterbrush (Purshia tridentata) and rechained in the opposite direction in 1969. Before chaining, the plant communities consisted of a pinyon/juniper woodland with an old growth matrix interspersed with islands of big sagebrush (Artemisia tridentata) representing lower seral stages produced by wildfires and/or woodcutting. When the tree canopies in the old growth pinyon areas were virtually closed, all but the most shade, litter, and competition-tolerant species were eliminated from the understory.

The site we selected supported a dense stand of big sagebrush, with pinyon saplings emerging through the one-meter-high shrub canopy (Fig. 1). Besides big sagebrush, the community occasionally supports bitterbrush, green ephedra (Ephedra viridis), horsebrush (Tetradymia canescens), and desert peach (Prunus andersonii). The understory under the dense shrub canopy was virtually bare, with occasional plants of squirreltail (Sitanion hystrix), and various forbs. Details of the community are described by Blackburn et al. (1969) and Young and Evans (1973).

Soils at the study site comprised Mollic Haplargids, with a $20-$ to $35-\mathrm{cm}$ ochric epipedon over a light yellowish-brown, gravelly-clay loam-argillic horizon (Blackburn et al., 1969).

\section{Herbicide Treatments}

In October 1971, we established plots, 10 by $10 \mathrm{~m}$, in a randomized block design with four replications. We applied the herbicides to the crown area of each pinyon sapling rooted in a plot by pouring the material on top of the tree crown. Treatments consisted of karbutilate (tert-butylcarbamic acid ester with 3-( $m$-hydroxyphenyl)-1,1dimethylurea) formulated as a $10 \%$ active ingredient (a. i.) granular at rates of 0.7 and $1.4 \mathrm{~g}$ a. i. per tree; 


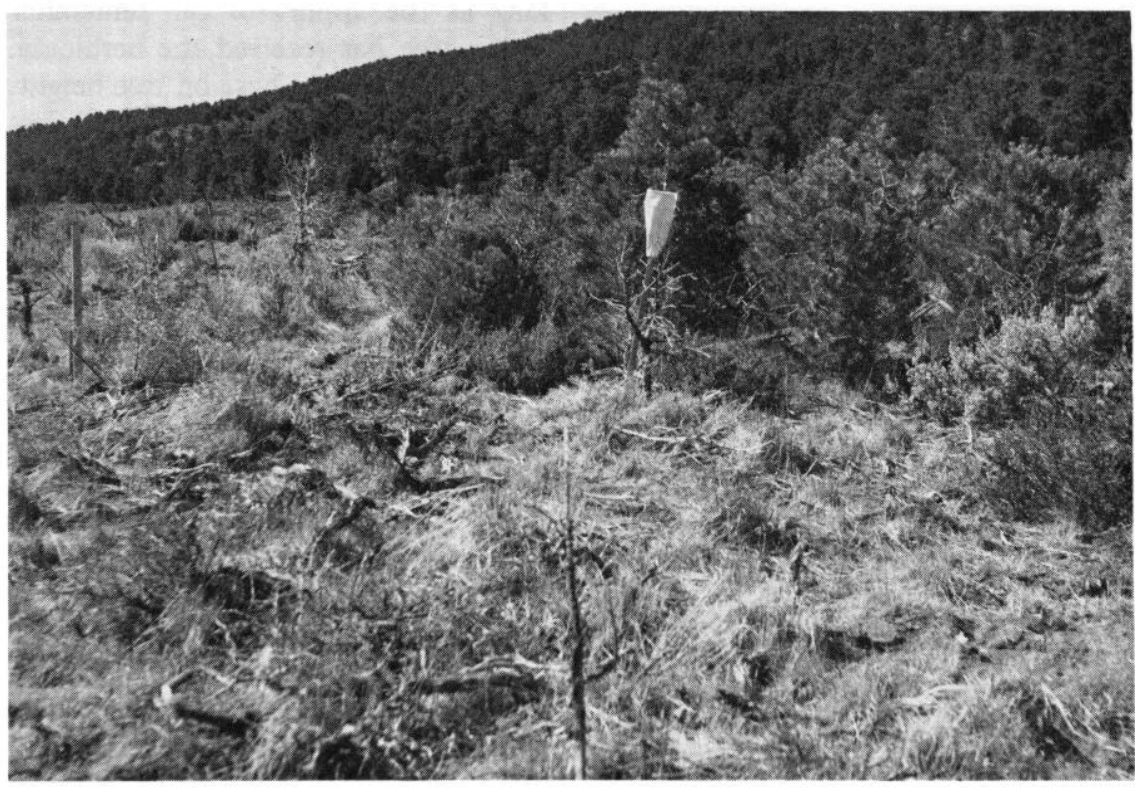

Fig. 1. Dense stand of one-leaf pinyon saplings emerging from canopy of big sagebrush. Old growth stand is in background.

karbutilate formulated as $60 \%$ a. i. tablets applied at the same rates; and picloram (4-amino-3,5,6-trichloropicolinic acid) formulated as $2.3 \%$ a. i. on ammonium sulfate beads applied at the same rates of active ingredients as the karbutilate. The rates of herbicides used were based on several years of testing of these materials on one-leaf pinyon at this and other sites in Nevada. Besides the herbicide treatments, we cut and removed from the plots all pinyon saplings (there were no larger trees), and cut and removed all trees and shrubs, except bitterbrush, as additional treatments.

In October, 1972, on an adjacent area, we applied picloram formulated as $10 \%$ a. i. granulars on sand cores at rates of $0.35,0.7$, and $1.4 \mathrm{~g} /$ tree.

\section{Sampling}

We determined the density and height of all trees on each plot and the density and herbage cover of all shrub species in each plot when the experiment was established. The cover of crested wheatgrass was also estimated. Each subsequent year we recorded symptoms of injury, mortality, or both of pinyon trees. Herbage yield and density of crested wheatgrass plants were determined from $4-\mathrm{m}^{2}$ plots clipped in each treatment. The herbage yield plots were stratified under and between trees. Shrub cover and density were recorded annually. In 1974, the plots were inadvertently grazed, so cover estimates of crested wheatgrass were substituted for herbage yield.

\section{Results}

The spectrum of activity for the two herbicides used is very different. Karbutilate is a soil-active herbicide that is relatively nonselective. Picloram is foliar-active when applied as a spray to leaves, but it is also soil-active when used as a granular material for basal crown area treatment. At the rates used in this study, picloram does not damage established perennial grasses.

\section{Control of One-leaf Pinyon}

The herbicides differ in the symptoms they produced on one-leaf pinyon saplings. By the end of the first season after the application of picloram, most trees had partial or total year after application of herbicides. leaf chlorosis (Table 1). Except for a few trees that rapidly dropped their needles, the trees treated with granular formulation of karbutilate were much slower to develop chlorotic needle symptoms. The trees treated with the tablet form of karbutilate were extremely slow to develop injury symptoms. Many trees that eventually died did not develop symptoms until the second season after application of the herbicide tablets.

In most treatments, occasional single trees showed no herbicide injury symptoms, even though all other trees in the treatment area died. We attributed these escapes to misses when the herbicide was applied. We tried spray painting and flagging trees as the herbicide was applied, but in dense patches of trees, occasional trees were missed. Skipping trees will be a problem in applying the technique on a practical basis, but the leaving of an occasional tree may be aesthetically valuable.

Picloram at 0.7 or $1.4 \mathrm{~g} /$ tree formulated as 2.3 or $10 \%$ granular and karbutilate at $1.4 \mathrm{~g} /$ tree as $10 \%$ granular material were very effective for control of pinyon saplings with heights of $2 \mathrm{~m}$ or less (Fig. 2). Karbutilate at $0.7 \mathrm{~g} /$ tree and picloram at $0.35 \mathrm{~g} /$ tree were effective on trees $0.5 \mathrm{~m}$ or less in height (Table 2).

The tablet formulation of karbutilate was quite ineffective (Table 2). Tablet formulations had been tried because of (a) concentration of active ingredients with reduced shipping cost, (b) ease of application: one aspirinsized tablet simply tossed under a tree, and (c) reduced damage to the herbaceous understory by concentration of

Table 1. Symptoms of herbicide injury (\% of trees treated) on one-leaf piny on saplings 1

\begin{tabular}{|c|c|c|c|c|c|}
\hline \multirow[b]{2}{*}{$\begin{array}{l}\text { Herbicide-formulation } \\
\text { rate }\end{array}$} & \multicolumn{4}{|c|}{ Injury } & \multirow[b]{2}{*}{$\begin{array}{l}\text { No injury } \\
\text { symptom }\end{array}$} \\
\hline & $\begin{array}{l}\text { Needle } \\
\text { drop }\end{array}$ & $\begin{array}{l}\text { Total } \\
\text { chlorosis }\end{array}$ & $\begin{array}{l}\text { Partial } \\
\text { chlorosis }\end{array}$ & $\begin{array}{c}\text { Spot } \\
\text { chlorosis }\end{array}$ & \\
\hline \multicolumn{6}{|l|}{ Karbutilate } \\
\hline \multicolumn{6}{|l|}{$10 \%$ gramular } \\
\hline $1.4 \mathrm{~g} /$ tree & 16 & 30 & 53 & & 1 \\
\hline $0.7 \mathrm{~g} /$ tree & & 23 & 45 & 30 & 2 \\
\hline \multicolumn{6}{|l|}{$60 \%$ tablet } \\
\hline $1.4 \mathrm{~g} /$ tree & & & 78 & 22 & \\
\hline $0.7 \mathrm{~g} /$ tree & & & & 22 & 78 \\
\hline \multicolumn{6}{|l|}{ Picloram } \\
\hline \multicolumn{6}{|l|}{$2.3 \%$ bead } \\
\hline $1.4 \mathrm{~g} /$ tree & & 86 & 12 & & 2 \\
\hline $0.7 \mathrm{~g} /$ tree & & 68 & 29 & 2 & 1 \\
\hline \multicolumn{6}{|l|}{$10 \%$ granular } \\
\hline $1.4 \mathrm{~g} /$ tree & & 92 & 8 & & \\
\hline $0.7 \mathrm{~g} /$ tree & & 54 & 44 & & 2 \\
\hline $0.35 \mathrm{~g} /$ tree & & 62 & 38 & & \\
\hline
\end{tabular}




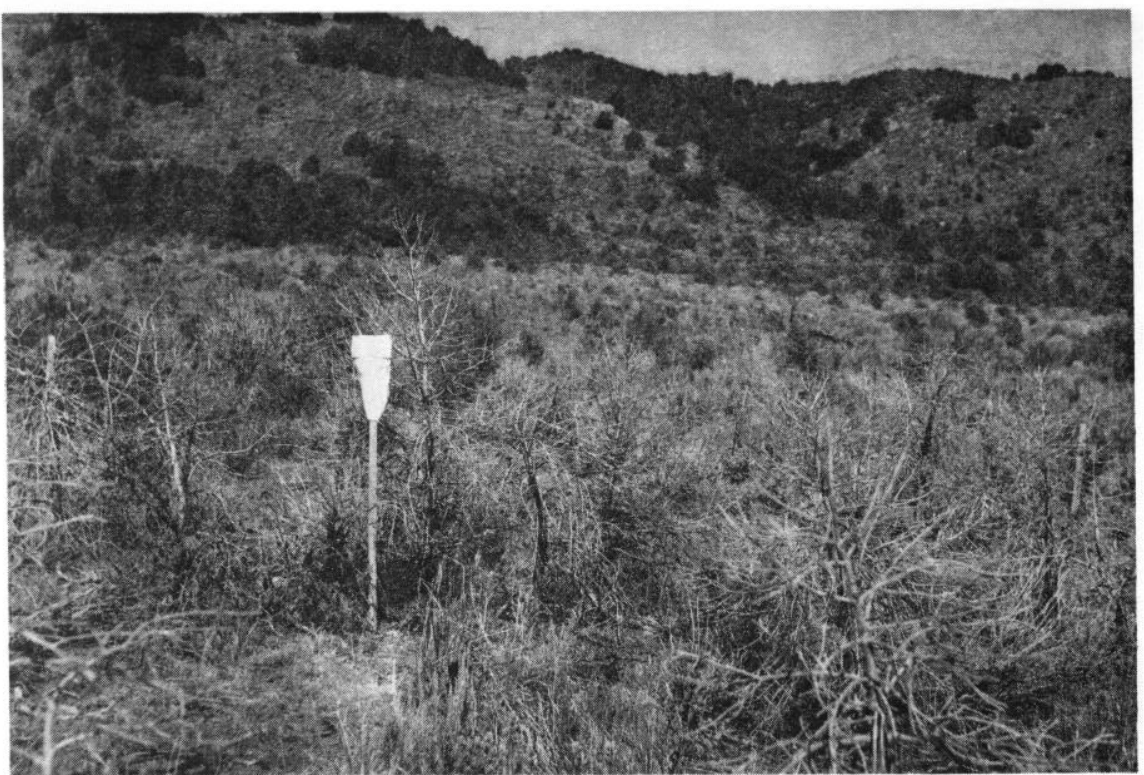

Fig. 2. Saplings of one-leaf pinyon controlled with $1.4 \mathrm{~g} /$ tree of herbicide karbutilate. the first application and reliance on lateral diffusion of the herbicide deep in the soil profile to reach enough tree roots.

Equivalent rates of $10 \%$ granular formulated karbutilate were very effective in controlling one-leaf pinyon saplings. Therefore, the solubility of the tablets, poor distribution of the herbicide around the rooting zone of the trees, or both probably accounts for ineffectual control.

\section{Application Techniques}

At 0.7 and $1.4 \mathrm{~g} /$ tree, we were applying 1.5 to $3.1 \mathrm{~kg} /$ ha of herbicide based on a mean density of 2,200 trees/ha. Because the granulars consist

of only $10 \%$ active ingredients, 15 to $31 \mathrm{~kg} / \mathrm{ha}$ of actual material must be packed out to the mountainside and distributed. The $2.3 \%$ a. i. picloram carried on beads of ammonium sulfate is a very convenient material to handle, in terms of ease of pouring, lack of dust, and conformity. But 65 to $135 \mathrm{~kg} /$ ha of material has to be transported.

We used plastic vials, cut down to provide the proper volume, to meter the correct dosage of herbicide to each tree. A $2.25-\mathrm{kg}$ bag of herbicide hung from a shoulder strap provided enough herbicide to treat about 1.4 ha of chaining at the lowest effective rate. Trees can be treated at a fast walk, as

Table 2. Control (\%) of one-leaf pinyon saplings in relation to height, 3 years after herbicides were applied. ${ }^{\mathrm{a}}$

\begin{tabular}{|c|c|c|c|c|c|c|}
\hline \multirow[b]{2}{*}{$\begin{array}{l}\text { Herbicide-formulation } \\
\text { rate }\end{array}$} & \multicolumn{6}{|c|}{ Tree ht (m) } \\
\hline & 0.25 & 0.5 & 1.0 & 1.5 & 2.0 & $\begin{array}{l}\text { Overall } \\
\text { controls }\end{array}$ \\
\hline \multicolumn{7}{|l|}{ Karbutilate } \\
\hline \multicolumn{7}{|l|}{$10 \%$ granular } \\
\hline $1.4 \mathrm{~g} /$ tree & 100 & 100 & 98 & 100 & 100 & 98 \\
\hline $0.7 \mathrm{~g} /$ tree & 100 & 100 & 98 & 94 & $-\mathrm{a}$ & 88 \\
\hline \multicolumn{7}{|l|}{$60 \%$ tablet } \\
\hline $1.4 \mathrm{~g} /$ tree & 84 & 88 & 74 & 64 & 0 & 78 \\
\hline $0.7 \mathrm{~g} /$ tree & 64 & 50 & 40 & 23 & - & 48 \\
\hline \multicolumn{7}{|l|}{ Picloram } \\
\hline \multicolumn{7}{|l|}{$2,3 \%$ bead } \\
\hline $1.4 \mathrm{~g} /$ tree & 98 & 98 & 100 & 100 & 100 & 98 \\
\hline $0.7 \mathrm{~g} /$ tree & 100 & 100 & 98 & 100 & 100 & 98 \\
\hline \multicolumn{7}{|l|}{$10 \%$ granular } \\
\hline $1.4 \mathrm{~g} /$ tree & 100 & 100 & 100 & 98 & 100 & 98 \\
\hline $0.7 \mathrm{~g} /$ tree & 100 & 100 & 100 & 94 & - & 98 \\
\hline $0.35 \mathrm{~g} /$ tree & 100 & 100 & 94 & - & 52 & 78 \\
\hline
\end{tabular}

${ }^{\mathrm{a}}$ Dash indicates this height class did not occur in treatments. The height class distribution was carried among treatments, so overall control is not the mean of control by height classes. long as the applicator can remember which tree has received the herbicide. For a variable-rate base on tree height, we applied 1 vial $(0.7 \mathrm{~g})$ for small (less than $1.5 \mathrm{~m})$ and 2 vials $(1.4 \mathrm{~g})$ for large saplings.

\section{Shrub Response}

The first response of shrubs to the herbicide treatments was rather limited. If the shrubs were rooted under the canopy of the pinyon, they were killed, but if they were rooted between the crowns, no injury resulted. The clonal species, desert peach and currant, usually had only a part of each clump killed, unless the entire clump was under the tree canopies.

We were especially interested in the susceptibility of bitterbrush to the herbicides. At first, we tried to establish a safe distance from treated trees for bitterbrush in relation to one-leaf pinyon control. Experience has shown that the simplest rule of thumb is that as long as bitterbrush or other shrubs are not primarily rooted under the crowns of the pinyon saplings, chances of injury are negligible.

The attempted removal of shrubs by chopping provided a dramatic change. The crown cover of the rootsprouting shrubs, desert peach and currant, increased by $64 \%$ on two of the four replications of the handchopped plots. On the other two replications, by chance, these shrubs did not occur before cutting. The rapid growth of desert-peach root sprouts after mechanical removal of the aerial parts has been noted before (Young and Evans, 1973).

\section{Herbaceous Response}

The crested wheatgrass stand on the treatment area was very stable during the experiment (Table 3). None of the herbicide treatments influenced stand density. Even though stand density was not reduced and crested wheatgrass dominated the understory, yield did not increase when trees were controlled. Yield increased only when the trees or shrubs or both were cut and removed. The increase in production partly resulted from increased production by the perennial grasses, but it largely represented increased downy brome (Bromus tectorum) production in the circle of litter where the trees were removed.

Why did production increase on the handcut plots and not on the herbicide treatments? The litter accumulation 
Table 3. Total herbage yield ( $\mathrm{kg} / \mathrm{ha})$ and density $/ \mathrm{m}^{2}$ of crested wheatgrass. ${ }^{\mathrm{a}}$

\begin{tabular}{|c|c|c|c|c|c|}
\hline \multirow{2}{*}{$\begin{array}{l}\text { Herbicide-formulation } \\
\text { rate }\end{array}$} & \multicolumn{2}{|c|}{1972} & \multicolumn{2}{|c|}{1973} & \multirow{2}{*}{$\frac{1974}{\text { Density }}$} \\
\hline & Yield & Density & Yield & Density & \\
\hline Control & 510 & 10.1 & $430 \mathrm{~b}$ & 9.1 & 11.1 \\
\hline $\begin{array}{l}\text { Karbutilate } \\
10 \% \text { granular } \\
1.4 \mathrm{~g} / \text { tree } \\
0.7 \mathrm{~g} / \text { tree }\end{array}$ & $\begin{array}{l}430 \\
480\end{array}$ & $\begin{array}{l}8.4 \\
7.6\end{array}$ & $\begin{array}{l}310 \mathrm{~b} \\
300 \mathrm{~b}\end{array}$ & $\begin{array}{r}11.8 \\
8.9\end{array}$ & $\begin{array}{r}9.8 \\
10.9\end{array}$ \\
\hline $\begin{array}{r}60 \% \text { tablet } \\
1.4 \mathrm{~g} / \text { tree } \\
0.7 \mathrm{~g} / \text { tree }\end{array}$ & $\begin{array}{l}390 \\
410\end{array}$ & $\begin{array}{l}6.7 \\
9.1\end{array}$ & $\begin{array}{l}280 \mathrm{~b} \\
320 \mathrm{~b}\end{array}$ & $\begin{array}{r}7.6 \\
10.1\end{array}$ & $\begin{array}{l}8.1 \\
9.4\end{array}$ \\
\hline $\begin{array}{l}\text { Picloram } \\
2.3 \% \text { bead } \\
1.4 \mathrm{~g} / \text { trec } \\
0.7 \mathrm{~g} / \text { tree }\end{array}$ & $\begin{array}{l}460 \\
380\end{array}$ & $\begin{array}{l}8.7 \\
7.8\end{array}$ & $\begin{array}{l}370 \mathrm{~b} \\
310 \mathrm{~b}\end{array}$ & $\begin{array}{l}8.9 \\
8.8\end{array}$ & $\begin{array}{l}9.1 \\
8.9\end{array}$ \\
\hline Trees cut and removed & 500 & 9.3 & 890 a & 8.9 & 10.1 \\
\hline $\begin{array}{l}\text { Trees and shrubs cut } \\
\text { and removed }\end{array}$ & 480 & 8.7 & $980 \mathrm{a}$ & 9.3 & 10.0 \\
\hline
\end{tabular}

a Means followed by the same letter are not significant at the 0.01 level of probability, as determined by Duncan's multiple range test. Columns without letters do not significantly differ among means.

beneath the herbicide-treated trees, which was substantial before the herbicides were applied, increased with the needle drop from the dead trees. This blanket of litter failed to support downy brome or other annuals. Not only did the handcut plots not have the needle drop from trees, but also the preexisting litter areas were greatly disturbed by the cutting of the bushy pinyon saplings.

Probably, the shrubs also responded to the removal of the pinyon layer, and this response limited the accelerated production of crested wheatgrass.
Where we hand cut the trees and shrubs, herbaceous production increased more than when we cut the trees alone (Table 3). The regrowth of root-sprouting shrubs on two replications of this treatment probably prevented this increase in production from being statistically significant.

\section{Significance to Management}

If either of these herbicides is registered for use on rangelands, land managers will have a valuable tool for extending the effective life span of pinyon chaining. Within-state registration for use of picloram for juniper control already exists. ${ }^{1}$

By applying the materials by hand to individual trees, we obtained a level of selectivity that permitted control of pinyon saplings without undue damage to adjacent bitterbrush plants.

An excellent stand of crested wheatgrass was on the study area before the herbicides were applied. In many chainings, areas of dense young pinyon/juniper trees contain no valuable browse or herbaceous species. Under these conditions, broadcast herbicide treatments and revegetation are required.

\section{Literature Cited}

Beeson, C. D. 1974. The distribution and synecology of Great Basin pinyonjuniper. MS Thesis, University of Nevada, Reno. $96 \mathrm{p}$.

Blackburn, W. H., P. T. Tueller, and R. E. Eckert, Jr. 1969. Vegetation and soils of the Churchill Canyon watershed. Agr. Exp. Sta. Univ. of Nevada Bull. R-45. $154 \mathrm{p}$.

Monroe, L. 1974. Condition and trend of selected Nevada deer ranges. MS Thesis, Univ. of Nevada, Reno. 108 p.

Young, J. A., and R. A. Evans. 1973. Downy brome-intruder in the plant succession of big sagebrush communities in the Great Basin. J. Range Manage. $26: 410-415$.

${ }^{1}$ Torell, P. J., and Higgins, R. E. 1975. Western Juniper Control with Picloram. Proc. Weed Science Society of America, Washington, D.C. p. 21. 